\title{
Shaping the discussion
}

\section{The current move toward a presidential debate highlighting science and technology may at least provide the impetus for political discussion in these areas to go beyond hot button issues.}

"I 'm curious, is there anybody on the stage that does not agree-believe in evolution?" This question, posed to presidential candidates at the MSNBC debate in May 2007, was answered by a simple show of hands. The subject of the question is a topic previously discussed in these pages, but the form of the question, and its answer, also deserve scrutiny. Is this what passes for addressing a scientific issue in a political debate? Aren't there hard scientific policy issues also to be discussed? What would the candidates' budget proposals for science and technology look like? Do they have priorities for research targeting specific diseases? Are there any initiatives we ought to know about (Manhattan or genome projects)? Who will advise them on science issues? As we go to press, an invitation co-sponsored by a number of organizations (http://www. sciencedebate2008.com) and signed by various science heavyweights has been sent to the current crop of candidates, throwing down the gauntlet for a debate highlighting science and technology. The time and place have been set (18 April 2008 in Philadelphia), though RSVPs have yet to be received. Whether or not this idea comes to fruition, it raises questions about what we expect from our political candidates in terms of this discussion.

When, in 1887, Joseph Kinyoun set up a single research room to investigate cholera, he did not need a presidential pat on the back or the US Congress to debate this enterprise. It was only with the will of policy makers and legislators, however, that this small seed led in 1901 to congressional appropriation of $\$ 35,000$ to construct a building housing research, in 1930 to additional funding and set up of research fellowships, in 1937 to a Cancer Institute that provided a model for future research institutes, and by 1966 to a budget expansion to greater than $\$ 1$ billion during the golden years of, you've guessed it, the National Institutes of Health (NIH). Thus, government involvement in promoting scientific research has in the past made American biomedical research a world leader. Obviously, lack of political will, or worse, antipathy, can damage what has been built.

So why should the president and applicants for the aforementioned position be expected to discuss science issues and policy matters? $\mathrm{He}$ or she may even argue that science and technology have not appeared to have a central role in presidential policy until surprisingly recently. It was during Eisenhower's presidency that James Killian was named the first official White House Science Advisor, giving clear recognition to the importance of the research endeavor. More recently, both George H.W.Bush and Bill Clinton maintained an Assistant to the President on Science and Technology, the prestigious prefix given to high-ranking officials in the White House. In addition, far from being disinterested, the current administration has made profound science policy decisions, including how money can be spent, for example, by imposing restrictions on federal funding of embryonic stem cell research, and of course the budget itself, which, after completion of the Clinton administration's initiative to double the NIH budget, has flattened, with the presidential budget proposal on 4 February 2008 proposing no funding increase for the $\mathrm{NIH}$ in 2009. In addition, there has been considerable media and scientificcommunity attention centered on the current administration's uses and abuses of science. All in all, this adds up to an impetus to scrutinize quite carefully what candidates plan to do in this area if they are elected. But rather than discuss only the politicians, it is perhaps pertinent to turn the lens on ourselves as well, and ask what we can do to promote a fruitful discussion regarding presidential plans in this area.

In 1964, the journal Science (Science 146, 1440-1445, 1964) covered an organization of 50,000 professionals that had set up a network of action centers across the United States, raised $\$ 500,000$ and taken out 3,000 radio spots to campaign for candidate Lyndon B. Johnson. In addition, a half-hour television slot introduced by Henry Fonda and involving scientists (televised scientists, talking to the public for $30 \mathrm{~min}$ about science and technology!) was aired. The group was largely motivated to rally against Senator Goldwater's position on nuclear weapons and was an indictment of his campaign by the very people who most understood 'the science behind the bomb. The group of professionals was called "Scientists and Engineers for Johnson-Humphrey." While this level and type of organized political movement was unprecedented and has not emerged so intensely since, the scientific community mobilizes now and again, such as in the 2001 letter co-signed by 80 Nobel laureates that urged President Bush to federally fund pluripotent stem cell research. Although such letters are more measured than the out-and-out activism of the movement against Goldwater, both received considerable media coverage. When scientists speak out, the public and the media are interested, not indifferent.

But we do not need to set up action centers across the nation to get involved. Whenever issues relevant to us, such as the latest NIH budget proposals, are coming up for debate, a simple phone call to your elected representatives' offices to put forth your point of view is worthwhile- they are in the halls of power to represent you as part of their constituency, after all. In the case of presidential candidates, an obvious pro-active move is to familiarize yourself with candidates' positions and factor this into voting; if there isn't a section on science and technology on the candidate's website under the Issues column, perhaps contact the campaign and ask why not. Alternatively, the front half of Science and Nature are usually informationrich on candidates and issues arising during elections in the United States and other countries. In the end, greater discussion of science and science policy by our politicians, and particularly the candidates aiming for the most powerful positions in a democracy, can benefit both scientists and society, and we are the very people to facilitate and demand an accurate and meaningful discussion. Meanwhile, the potential White House Science advisors to Senators Clinton and Obama met to discuss science at the American Association for the Advancement of Science on 17 February 2008; whether the candidates themselves will follow suit is still up in the air. 